\title{
Formulation and Quality Evaluation of Modified Upma Mix from Foxtail Millet and Soy for Nutritional Security
}

\author{
Ketki Dhumketi, Alpana Singh* and Priyanka Agrawal
}

Department of Food Science and Technology, Jawaharlal Nehru Krishi Vishwa Vidyalaya, Jabalpur, MP, India

*Corresponding author

\section{A B S T R A C T}

\begin{tabular}{|l|}
\hline K e y w o r d s \\
$\begin{array}{l}\text { Foxtail millet, Soybean, } \\
\text { Sensory attributes, } \\
\text { Nutritional quality, } \\
\text { Cooking quality, Hunter } \\
\text { colour analysis }\end{array}$ \\
\hline Article Info \\
\hline $\begin{array}{l}\text { Accepted: } \\
\text { 10 January } 2018 \\
\text { Available Online: } \\
\text { 10 February } 2018\end{array}$ \\
\hline
\end{tabular}

Upma mix using different combinations of foxtail millet, semolina and soy was developed by modified recipe followed by its sensory, proximate, hunter colour and cooking quality evaluation. The modified upma mix prepared from $65 \%$ foxtail millet, $30 \%$ semolina and $5 \%$ soy was found to be highly acceptable in terms of all sensory attributes. The cooked upma contains moisture content from 37.42 to $40.21 \%$, protein 11.82 to $12.95 \%$, fat 6.30 to $8.12 \%$, ash 2.05 to $3.91 \%$, carbohydrate content 30.39 to $38.44 \%$ and provided energy value 244.88 to $257.74 \mathrm{Kcal} / 100 \mathrm{~g}$. The $\mathrm{L}^{*}$ value of cooked upma was decreased with increasing level of foxtail millet during hunter colour analysis. The modified upma was found to be taken more cooking time as compared to control sample prepared from wheat semolina and black gram dal. The upma formulation prepared from $95 \%$ foxtail millet and $5 \%$ soy exhibited higher water uptake and rehydration ratio whereas solids in cooking water was highest in formulation prepared from 55\% foxtail millet, $40 \%$ semolina and $5 \%$ soy. The developed upma can offer inherent health benefits and can also open up better avenues for utilization of millet products for nutritional security.

\section{Introduction}

Upma is a traditional Indian breakfast dish, cooked as a thick porridge from dry roasted semolina. Various seasonings and vegetables are often added during cooking depending on individual preferences. The indigenous instant food products are prepared at home since ages, but due to the availability of wide range of instant food products in recent years, the consumers are more keen to use the products available in the market using convenient packages at reasonable rate (Unika and Jaffar, 2014).
Millets are unique among the cereals because of their richness in calcium, dietary fibre, polyphenols, carbohydrates (70-80\%) and protein $(9-14 \%)$. It is a gluten-free cereal an excellent source for people suffering from celiac disease and also rich in phytochemicals which help to lower cholesterol level and reduced cancer risk due to its phytate content (Shadang and Jaganathan, 2014). The nutritional qualities of millet have been well recorded (Hulse et al., 1980), its utilization for food is confined to the traditional consumers in tribal populations, mainly due to nonavailability of consumer friendly, ready-to-use 
or ready-to-eat products as are found for rice and wheat.

Foxtail is minor millet which also called as Italian millets commonly known as kangni, korra, navana, tenai, kakun and rala (Pawar and Pawar, 1997). This millet is a major source of protein, fibre, carbohydrate and other micronutrients in daily diet and thus positively impact on health (thathola, 1999). It is rich source of some essential amino acid mainly leucine, vitamins (thiamin, riboflavin niacin), minerals (calcium, manganese, potassium) and beneficial for diabetic population (Singh et al., 2003). Soybeans protein has been found to reduce the risk of coronary heart disease when consumed as part of a diet low in saturated fat and cholesterol (Tripathi and Misra, 2005).

Foxtail millet has not utilized so far for the preparation of instant upma mix.

Therefore, the present investigation was undertaken to develop modified upma mix by incorporating foxtail millet and soybean and analyze its various quality parameters.

\section{Materials and Methods}

\section{Raw materials}

Foxtail millet (Seteria italica) was procured from Regional Agricultural Research Station, All India Coordinated Research Project on Small Millets, College of Agriculture, Rewa, Madhya Pradesh. Wheat semolina and soybean (Glycine max) were procured from the local market of Adhartal, Jabalpur.

The foxtail millet was de-husked using millet mill and then was converted into semolina (grits) using a flour mill by adjusting clearance between the rotating discs and the obtained semolina was passed through flour sieve to separate flour from semolina.
Soybean grains were thoroughly cleaned to remove the dust and other foreign materials. The cleaned grains were soaked in water for 68 hours and autoclaved for 20 minutes to remove the beany flavour and to enhance easy de-hulling. The autoclaved beans were cooled and dried at $60^{\circ} \mathrm{C}$ for about 24 hours. The dried beans were milled to make soy grits and sieved through $80-100$ mesh sieves to separate soy flour (Ajibola and Filani, 2015).

\section{Development and optimization of instant upma mix}

Preliminary studies were performed to identify the appropriate combinations of ingredients, appropriate cooking time and accordingly percentage of supplementation was established through sensory evaluation. Several formulations of raw materials were tried to arrive at the desired formulation with optimum percentage as recommended by acceptability studies. All experimental samples were prepared using the traditional method (Dhumketi et al., 2017) with slight modification. Various acceptability parameters such as colour and appearance, taste, texture, flavour, after taste and overall acceptability were considered as deciding factors by using the method described by Amerine et al., (1965).

Modified upma mixes prepared by substituting foxtail millet by replacing wheat semolina and black gram by soy in different proportion of foxtail millet, wheat semolina and soy (UM275:20:5, UM3-65:30:5, UM4-55:40:5, UM545:50:5, UM6-95:0:5) respectively. The control sample was prepared by using $95 \%$ semolina and 5\% black gram dal (UM1).

\section{Preparation of modified upma mix}

The foxtail millet semolina, soy grits and wheat semolina were roasted separately in non-stick pan on slow flame with constant 
stirring till it started to give characteristic aroma and colour. $10 \mathrm{ml}$ oil was heated in a pan and mustard seeds ( $0.50 \mathrm{~g})$ were fried, and roasted ingredients were added in a pan and mixed properly. Salt ( $3 \mathrm{~g})$, citric acid $(0.10 \mathrm{~g})$, tartaric acid $(0.10 \mathrm{~g})$, dried green chilies $(0.50$ $\mathrm{g})$, curry leaves $(0.30 \mathrm{~g})$, ginger $(2 \mathrm{~g})$, coriander leaves $(0.20 \mathrm{~g})$ were also added to the pan. The samples were cooled, packed in container and stored at ambient condition.

\section{Reconstitution of modified upma mix}

$100 \mathrm{~g}$ dry mixes of modified upma was reconstituted with measured amount of hot water $(200 \mathrm{ml})$ and stirred on low flame until the desired consistency was attained (started to leave the pan).

\section{Sensory evaluation of upma}

The sensory quality characteristics of the upma prepared from various upma mixes were evaluated by panel of 15 trained judges using nine point hedonic scale (1-dislike extremely, 2-dislike very much, 3-dislike moderately, 4dislike slightly, 5-neither like nor dislike, 6like slightly, 7-like moderately, 8-like very much and 9-like extremely) as described by Amerine et al., (1965).

\section{Proximate composition of instant upma mix}

The moisture content of the sample was determined using moisture meter, protein content by conventional Micro-Kjeldhal digestion and distillation procedure as given in AOAC (1992) using Pelican's Kel Plus digestion and distillation assembly. The fat, ash and crude fibre content of the sample was determined by the procedure as described in AOAC (1992) using Sox plus automatic fat analysis system, Muffle furnace \& automatic fibre analysis system (Make- Pelican) respectively. Total carbohydrate was estimated by subtracting the sum of moisture, protein, fat, ash and crude fibre from 100 (Merrill and Watt, 1973). The total energy value (Kcal) was calculated by using the Atwater factor method $\left[\left(\begin{array}{lll}9 & \mathrm{x} & \text { fat }\end{array}\right)+(4 \mathrm{x}\right.$ carbohydrate $)+(4 \times$ protein $)]$ as described by Nwabueze (2007).

\section{Hunter colour measurement}

Colour measurement of different cooked upma was done by using a Hunter colour measuring system and expressed in terms of $\mathrm{L}^{*}, \mathrm{a}^{*}, \mathrm{~b}^{*}$, according to the CIE method (1976). L* represents the lightness from white (100) to black (0). Red to green colour component was indicated by $\mathrm{a}^{*}$ values and yellow to blue colour components was indicated by the $b^{*}$ values.

\section{Cooking quality}

The cooking quality of the upma mix was analyzed by the determination of cooking time, water uptake, solids in cooking water and rehydration ratio as described by Tamilselvi et al., (2015).

\section{Cooking time}

Cooking time was determined by boiling $2.0 \mathrm{~g}$ of sample in $20 \mathrm{ml}$ distilled water, removing a few sample at different time intervals during cooking and pressing them between two glass plates until no white core was left..

\section{Water uptake}

The water uptake ratio was determined by cooking $2.0 \mathrm{~g}$ of sample in $20 \mathrm{ml}$ distilled water for a minimum cooking time in a boiling water bath and drain the superficial water from the cooked sample. The cooked sample was weighted accurately and the water uptake ratio was calculated as the ratio of final cooked weight to uncooked weight of the sample and converted to percentage. Water uptake = 
(weight of cooked sample / weight of uncooked sample) x 100.

\section{Solids in cooking water}

This was determined by drying an aliquot of the cooked water in an evaporated dish to evaporate the water. The weight of the empty petri dish (W1) and weight of petri dish with aliquot (W2) was recorded. The petri dish with aliquot after drying was recorded as (W3). The amount of solid in cooking water was calculated as W3-W1.

\section{Rehydration ratio}

Rehydration ratio (RR), a measure of water absorption by the dehydrated product was calculated using following equation as given by Basantpure et al., (2003).

$\mathrm{R}=\frac{W_{T}}{W_{d}}$

Where:

$\mathrm{Wr}(\mathrm{g})$ weight of the rehydrated upma mix

Wd (g) weight of the dry upma mix used for rehydration

\section{Statistical analysis}

The data obtained from various experiments were statistically analyzed. A complete randomized design was adopted for statistical analysis of data by following the procedure as described by Panse and Sukhatme (1963).

\section{Results and Discussion}

\section{Development and optimization of modified upma mix}

Various trials were conducted by using varying formulations of foxtail millet, semolina and soy keeping mustard seeds, dried spices (chilli, ginger, coriander and curry leaves) level constant with salt, citric acid, tartaric acid, hot oil and water. Accordingly upma mix was prepared with 45-95 percent foxtail millet, 10-50 percent semolina, 5-20 percent soy, 10-20 percent oil and 160-200 ml water for cooking. The control upma mix was prepared with wheat semolina (95 g), black gram $(5 \mathrm{~g})$, salt $(3 \mathrm{~g})$, mustard seeds $(0.50 \mathrm{~g})$, dried chilli $(0.50 \mathrm{~g})$, curry leaves $(0.50 \mathrm{~g})$, ginger $(2 \mathrm{~g})$, coriander leaves $(0.20 \mathrm{~g})$, citric acid $(0.10 \mathrm{~g})$, tartaric acid $(0.10 \mathrm{~g})$. In the primary sensory evaluation test, different upma were prepared from different formulations and were evaluated by panelists. The score for the products with 45-95 percent foxtail millet, 20-50 percent semolina, 5 percent soy, 15 percent oil were acceptable in terms of all sensory attributes. Panelists suggested the $15 \mathrm{ml}$ oil and $200 \mathrm{ml}$ water/100 gm instant mix for improving the texture and softness of modified instant upma mix as the upma mix with $10 \mathrm{ml}$ oil was too sticky in texture while with $20 \mathrm{ml}$ oil was very oily. Similarly, the pearl millet based upma dry mix was developed and ingredients were optimized by Balasubramanian et al., (2014) (Fig. 1).

They optimized the level of vanaspati to get desirable sensory characteristics after reconstitution. The instant soy-fortified upma mix was also prepared using the optimum level of ingredients by Yadav and Sharma (2008). Similarly Dharmaraj et al., (2016) prepared semolina from foxtail millet and evaluated its nutritional, physical and functional properties and Chithra and Sathiya (2008) developed soy incorporated adai, oothapam, pancake, vermicelli upma, vegetable biryani where soy was incorporated in different forms as per the suitability of the recipe. Deshpande and Posadri (2011) utilized the foxtail millet (Setaria italica) along with other flour for production of ready-to-eat snack products. 
Table.1 Sensory attributes of upma

\begin{tabular}{|c|c|c|c|c|c|c|}
\hline Formulations & $\begin{array}{c}\text { Colour \& } \\
\text { appearance }\end{array}$ & Taste & Flavour & Texture & $\begin{array}{c}\text { After } \\
\text { taste }\end{array}$ & $\begin{array}{c}\text { Overall } \\
\text { acceptability }\end{array}$ \\
\hline UM1 & 8.82 & 8.70 & 8.50 & 8.65 & 8.53 & 8.64 \\
\hline UM2 & 8.34 & 8.27 & 8.0 & 8.20 & 8.05 & 8.17 \\
\hline UM3 & 8.55 & 8.40 & 8.40 & 8.50 & 8.30 & 8.43 \\
\hline UM4 & 7.80 & 7.53 & 7.20 & 7.52 & 7.80 & 7.57 \\
\hline UM5 & 7.50 & 7.30 & 7.00 & 7.24 & 7.20 & 7.24 \\
\hline UM6 & 8.45 & 8.35 & 8.32 & 8.40 & 8.16 & 8.33 \\
\hline SEM & 0.037 & 0.045 & 0.057 & 0.037 & 0.045 & 0.016 \\
\hline CD at 5\% & 0.116 & 0.142 & 0.181 & 0.118 & 0.143 & 0.049 \\
\hline
\end{tabular}

Table.2 Proximate composition of cooked upma

\begin{tabular}{|c|c|c|c|c|c|c|c|}
\hline Formulations & $\begin{array}{c}\text { Moisture } \\
(\%)\end{array}$ & $\begin{array}{l}\text { Ash } \\
(\%)\end{array}$ & $\begin{array}{l}\text { Crude } \\
\text { fibre } \\
(\%)\end{array}$ & $\begin{array}{c}\text { Protein } \\
(\%)\end{array}$ & $\begin{array}{l}\text { Fat } \\
(\%)\end{array}$ & $\begin{array}{c}\text { Carbohydrate } \\
(\%)\end{array}$ & $\begin{array}{c}\text { Energy } \\
\text { value } \\
\text { (Kcal/100g) }\end{array}$ \\
\hline UM1 & 40.21 & 2.05 & 1.18 & 11.82 & 6.30 & 38.44 & 257.74 \\
\hline UM2 & 37.46 & 3.79 & 5.96 & 12.95 & 7.94 & 31.94 & 251.02 \\
\hline UM3 & 38.14 & 3.55 & 5.35 & 12.47 & 7.76 & 32.73 & 250.64 \\
\hline UM4 & 38.38 & 3.41 & 4.30 & 12.42 & 6.75 & 34.74 & 249.12 \\
\hline UM5 & 38.45 & 3.28 & 3.68 & 12.15 & 6.37 & 36.07 & 250.21 \\
\hline UM6 & 37.42 & 3.91 & 7.60 & 12.56 & 8.12 & 30.39 & 244.88 \\
\hline SEM & 0.008 & 0.096 & 0.034 & 0.009 & 0.013 & 0.014 & 0.014 \\
\hline CD@5\% & 0.025 & 0.303 & 0.108 & 0.027 & 0.043 & 0.042 & 0.044 \\
\hline
\end{tabular}

Table.3 Hunter colour value of cooked upma

\section{Formulations}

UM1

UM2

UM3

UM4

UM5

UM6

\section{Hunter colour analysis}

\begin{tabular}{|c|c|c|c|}
\hline $\mathbf{L}^{*}$ & $\mathbf{a}^{*}$ & $\mathbf{b}^{*}$ \\
\hline 64.01 & 2.25 & 16.91 \\
\hline 59.79 & 2.08 & 18.35 \\
\hline 62.39 & 2.91 & 17.48 \\
\hline 62.45 & & 3.66 & 19.97 \\
\hline 63.52 & 3.31 & 18.79 \\
\hline 55.53 & 3.76 & 19.09 \\
\hline
\end{tabular}


Table.4 Cooking quality of modified upma mix

\begin{tabular}{|c|c|c|c|c|}
\hline Formulations & $\begin{array}{c}\text { Cooking time } \\
\text { (min.) }\end{array}$ & $\begin{array}{c}\text { Water uptake } \\
(\mathbf{\%})\end{array}$ & $\begin{array}{c}\text { Solids in } \\
\text { cooking }\end{array}$ & $\begin{array}{c}\text { Rehydration } \\
\text { ratio }\end{array}$ \\
\hline UM1 & 5 & 196 & 4.05 & 2.80 \\
\hline UM2 & 7.10 & 210 & 3.12 & 3.40 \\
\hline UM3 & 7 & 230 & 3.10 & 3.35 \\
\hline UM4 & 7 & 235 & 4.15 & 3.20 \\
\hline UM5 & 7 & 225 & 4.10 & 3.08 \\
\hline UM6 & 7.30 & 240 & 3.00 & 3.50 \\
\hline
\end{tabular}

Fig.1 Flow chart of preparation of modified upma mix

Roasting of raw materials separately

Frying of mustard seeds in hot oil

$$
\text { Mixing all the ingredients }
$$

Cooled, packed and stored at room temperature

\section{Different formulations of upma mix}

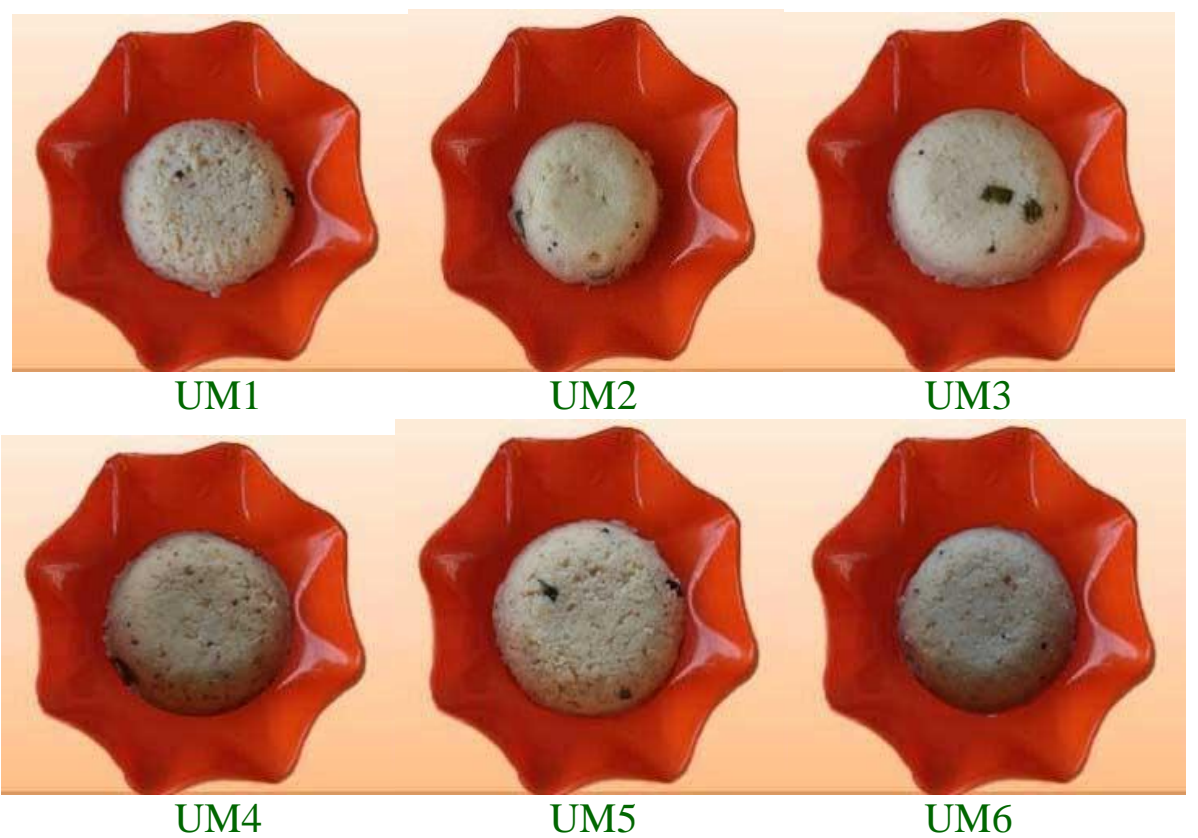

\section{Sensory analysis of upma}

The scores for sensory parameters of upma formulation (UM3) prepared from $65 \%$ foxtail millet, $30 \%$ semolina and $5 \%$ soy was highest in terms of colour and appearance (8.55), taste (8.40), flavour (8.40), texture (8.50), after taste (8.30) and overall 
acceptability (8.43) table 1 . This might be due to addition of fine foxtail millet semolina and soy grits in appropriate combination resulting good colour, nice taste and fine texture of upma. The supplementation of foxtail millet in formulations with higher percentage resulted good acceptability of upma. The present findings are in contrast with the results reported by Poongodi et al., (2010) with regards to noodle prepared from composite flour (millet, wheat and soy). Whereas Punia et al., (2003) prepared acceptable ladoo and shankarpara by substituting maida with $50 \%$ kangni flour. Similarly Itagi et al., 2012; Srivastava et al., 2014; Adegunwa et al., 2014 reported the acceptable level of foxtail millet flour at $80 \%$, $50 \%$ and $100 \%$ respectively.

\section{Proximate composition of cooked upma}

Data depicted in table 2 shows the proximate composition of foxtail millet based cooked upma. The moisture content of upma ranged from 37.42 to $40.21 \%$, protein 11.82 to $12.95 \%$, fat 6.30 to $8.12 \%$, crude fibre 1.18 to $7.60 \%$, ash 2.05 to $3.91 \%$, carbohydrate 30.39 to $38.44 \%$ and energy value was found to be 244.72 to $257.74 \mathrm{Kcal} / 100 \mathrm{~g}$. The overall nutritional quality of instant upma mix with substitutions of foxtail millet semolina was higher than control sample. Similar results were reported by Sambavi et al., (2015) and Punia et al., (2003) with regards to development of cookies using a combination of foxtail millet and wheat flour and nutritional evaluation of kangni (Setaria italic) respectively. The fibre content was increased with increased supplementation of foxtail millet. Similar findings were reported by Poongodi et al., (2010) with regard to millet flour blend.

\section{Hunter colour values of cooked upma}

As can be seen from the table 3 , the $\mathrm{L}^{*}$ value was decreased with supplementation of foxtail millet semolina as compared to control. Products prepared with foxtail millet, semolina and soy showed significant differences in colour values which may be due to incorporation of different type of ingredients in different concentration in the mix. The wide range in lightness values observed for the samples may also be due to the processing conditions such as roasting time and temperature. The reverse trend was observed in $a^{*}$ and $b^{*}$ values of different cooked upma formulations.

\section{Cooking quality}

Cooking characteristics of upma mix are given in table 4 . The cooking time ranged from 5-7.30 minutes for modified upma mix. The modified sample (UM6) needs maximum time $(7.30 \mathrm{~min}$.$) for cooking while control$ sample needs $5 \mathrm{~min}$. Contrast result reported by Poongodi et al., (2010) for noodles developed from composite millet flour. The time taken for cooking of upma increased with increase in the level of incorporation of millet. Similar result reported by Thilagavathi et al., (2015) with regards to standardization of extruded products using modified millet flour and pulse flour.

The water uptake of modified upma mixes was found to be highest in the formulation UM6 supplemented with foxtail millet and soy grits whereas lowest in UM1 prepared from wheat semolina and black gram dal. Similar result was also obtained in noodle prepared from millet incorporated flour by Vijayakumar et al., (2010) whereas contrast result was reported by Gull et al., (2015) with regards to millet supplemented pasta.

The solids in cooking water were higher in control sample and lower in foxtail millet based modified upma mix. The increase in supplementation of foxtail millet decreases the solid in cooking water that proved the percent loss of solids was minimum for 
foxtail millet. Similar result was also obtained in noodle prepared from millet incorporated flour by Vijayakumar et al., (2010) whereas contrast result was reported by Gull et al., (2015) with regards to millet supplemented pasta.

The rehydration ratio with different combinations of upma mix was found to be highest in modified upma mix and lowest in control sample. Similar result was reported by Balasubramanian et al., (2014) as they reported that the rehydration ratio was found to be from 2.4 to 3.3 in pearl millet semolina.

It can be concluded that replacement of wheat semolina by foxtail millet and soy exhibited excellent nutritional quality along with good sensory profile. Foxtail millet and soy can be used successfully for the preparation of ready to cook fod products. The developed upma can offer inherent health benefits and can also open up better avenues for utilization of millet products for nutritional security.

\section{References}

Adegunwa MO, Ganiyu AA, Bakare HA and Adebowale AA. 2014. Quality evaluation of composite millet-wheat chinchin. Agriculture and Biology Journal of North America. 5(1): 33-39.

Ajibola CF and Filani A. 2015. Storage stability of deep-fried cowpea products (akara) incorporated with soy-flour and aframomum danielli. British Journal of Applied Science and Technology. 8(2): 204-212.

Amerine MA, Pangborn RM and Roessler EB. 1965. Principle of sensory evaluation of foods. Academic Press, New York. 349p.

AOAC. 1992. Official methods of analysis 16 edition. Association of official Analytical Chemistry Inc., Arlington VA.

Balasubramanian S, Deep NY, Jaspreet K and Tanupriya A. 2014. Development and shelf life evaluation of pearl millet based upma dry mix. Journal of Food Science and technology. 51(6): 1110-1117.

Balasubramanian S, Deep NY, Jaspreet K and Tanupriya A. 2014. Development and shelf life evaluation of pearl millet based upma dry mix. Journal of Food Science and Technology. 51(6): 1110-1117.

Basantpure D, Kumbhar BK and Awasthi P. 2003. Optimization of level of ingredients and drying air temperature in development of dehydrated carrot halwa using response surface methodology. Journal of Food Science and Technology. 40, 40-44.

Chithra R and Sathiya V. 2008. Effect of incorporation of soy products on the glycaemic index and glycaemic load of selected Indian food. Indian Journal of Nutrition and Dietetics. 45, 228-235.

CIE, "Commission International de 1 ' Éclairage," 1976. http://www.cie.co.at.

Deshpande HW and Poshadri A. 2011. Physical and sensory characteristics of extruded snacks prepared from foxtail millet based composite flours. International Food Research Journal. 18, 751-756.

Dharmaraj Usha, Rao BVS, Sakhare SD and Inamdar AA. 2016. Preparation of semolina from foxtail millet (Setaria italica) and evaluation of its quality characteristics. Journal of Cereal Science. $68,1-7$.

Dhumketi K, Singh A and Rajput LPS. 2017. Suitability of foxtail millet semolina and soy grits for the formulation of instant upma mix. International Journal of Chemical Studies. 5(5): 75-79.

Gull A, Pradesh K and Kumar P. 2015. Optimization and functionality of millet supplemented pasta. Food science and technology, Campinas. 35(40): 626-632.

Hulse, J.H., Laing, E.M. and Pearson, O.E. 1980. Sorghum and the Millets: Their Composition and Nutritive Value. New York, NY: Academic Press. 187-193.

Itagi S, Naik R, Bharati P and Sharma P. 2012. Readymade foxtail millet mix for diabetics. International Journal of Science and Nature. 3(1): 47-50. 
Merrill AL and Watt BK. 1973. Energy value of foods: basis and derivation. In: Agriculture Handbook No. 74, United States Department of Agriculture, Washington. Pp 2-4.

Nwabueze TU. 2007. Nitrogen solubility index and amino acid profile of extruded African breadfruit (T.africana) blends. Nigerian Food Journal. 25, 23-35.

Panse and Sukhamte PV. 1963. Statistical methods for agricultural workers, Indian council for agricultural research, New Delhi, India.

Pawar VS \& Pawar VD (1997). Malting characteristics and biochemical changes of foxtail millet. Journal of Food Science and Technology. 30, 416-418.

Poongodi V, Jemima BM and Srinivasan T. 2010. Quality evaluation of noodles from millet flour blend incorporated composite flour. Journal of Scientific and Industrial Research. 69(1): 48-54.

Punia D, Dalal A and Sindhu S. 2003. Nutritional evaluation of kangni (Setaria italica): An underutilised millet and sensory evaluation of value added products from kangni. In: Recent Trends in Millet Processing and Utilization, CCS Hisar Agrilultural University Hisar, India. Pp 32-37.

Sambavi A, Sabaragamuwa RS and Suthakaran R. 2015. Development of cookies using a combination of foxtail millet and wheat flour. International Journal of Scientific and Technology Research. 4(10): 294295.

Shadang C and Jaganathan D. 2014. Development and standardisation of formulated baked products using millets. International Journal of Research in Applied, Natural and Social Sciences. 2(9): 75-78.

Singh G, Sharma S, Srivastava S. 2003. Processing and nutritional aspects of Foxtail. Beverage and Food world. Pp 2023.

Srivastava S, Sakhare SD and Indrani D. 2014. Preparation of multigrain semolina blend for upma: its formulation, rheology, physicochemical, textural and nutritional characteristics. Journal of Texture Studies. 45(6): 452-461.

Tamilselvi E, Sudha P, Kharthika S and Preethi VS. 2015. Studies on cooking qualities of minor millets. International Journal of Tropical Agriculture. 33(2): 1365-1367.

Thathola A. 1999. Development of weaning food based on foxtail millet and barnyard millet for infants. MSc thesis. GB Pant University of Agriculture and Technology, Pantnagar, UP, India.

Thilagavathi T, Kanchana S, Banumathi $\mathrm{P}$, Hemalatha G, Vanniarajan C, Sundar M and Ilamaran M. 2015. Physico-chemical and functional characteristics of selected millets and pulses. Indian Journal of Science and Technology. 8(57): 147-155.

Tripathi, A.K. and Misra, A.K. 2005. SoybeanA consummate functional food: A review. Journal of Food Science and Technology. 42: 111-119.

Yadav DN and Sharma GK. 2008. Optimization of soy-fortified instant upma mix ingredients using response surface methodology. Journal of Food Science and Technology. 45(1): 56-60.

\section{How to cite this article:}

Ketki Dhumketi, Alpana Singh and Priyanka Agrawal. 2018. Formulation and Quality Evaluation of Modified Upma Mix from Foxtail Millet and Soy for Nutritional Security. Int.J.Curr.Microbiol.App.Sci. 7(02): 888-896. doi: https://doi.org/10.20546/ijcmas.2018.702.112 